ZatącZnils

DOI 10.21697/zk.2021.8.04
Uznanie autorstwa-Użycie niekomercyjne-Bez utworów zależnych

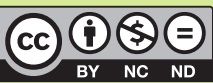

Załącznik Kulturoznawczy 8/2021

TEMAT NUMERU (1): POSZERZANIE POETYKI

\title{
JEAN BAUDRILLARD. „SOCJOLOGIA” I POETYKA
}

TOMASz WóJcIK

Wydział Polonistyki UW

Faculty of Polish Studies, University of Warsaw

tomasz.wojcik@uw.edu.pl

ORCID: 0000-0001-8291-0961

\section{UWAGI WPROWADZAJĄCE}

Komentarza wymaga przede wszystkim podtytuł tego szkicu - ujęcie terminu socjologia w cudzysłów. Cudzysłów ten nie oznacza oczywiście w żadnej mierze dezawuowania myśli Jeana Baudrillarda. Chodzi o przebieg jego biografii intelektualnej i naukowej, który wyznacza stopniowe odchodzenie od socjologii w jej - mówiąc najogólniej - klasycznej postaci. Nie mogło być inaczej w przypadku autora, który tak uporczywie wypowiadał się przeciwko socjologii, który tylokrotnie ogłaszał koniec przedmiotu jej badań - „implozję”, „likwidację”, „zanik” czy „kres” sfery społecznej. Jak wiadomo, Baudrillard rzadko i niechętnie utożsamiał się z którąkolwiek z nauk humanistycznych, szczególnie w późniejszych latach, kiedy do swojego pisarstwa anektował języki, style i metody coraz to innych dyscyplin. Ostatecznie jego myśl sytuuje się w kręgu i na pograniczu socjologii, filozofii, filozofii kultury, antropologii, psychologii społecznej, politologii, medioznawstwa, ekonomii i - co dla tego wywodu najważniejsze - w jakimś zakresie i w jakimś sensie literaturoznawstwa. W popularnych opracowaniach Baudrillard bywa zwykle przedstawiany jako „socjolog” lub „filozof”.

Spośród tych wszystkich dziedzin zdecydowałem się wskazać socjologię, ponieważ nazwa ta chyba jednak najtrafniej określa obszar jego zainteresowań i badań, ale z koniecznym cudzysłowem, który ma przypominać, że jest to socjologia „miękka”, socjologia rozproszona wśród stylów myślenia i pisania właściwych wielu różnym dyscyplinom. Tak rozumie tę „miękkość” Agnieszka Ogonowska: „na próżno [...] szukać [w tekstach 
Baudrillarda - przyp. T.W.] »twardych« danych empirycznych, konsekwentnie prowadzonych badań i wynikających z nich danych statystycznych"1.

Zastrzeżenie drugie ma za przedmiot uwzględniony materiał. Dzieło francuskiego myśliciela jest niewątpliwie trudnym wyzwaniem - nie tylko z powodu, jak zaznaczyłem, erudycyjnej wielości języków, którymi operuje, ale również (i najprościej) z powodu swojej nieprzeciętnej objętości: obejmuje bowiem - brzmi to niewiarygodnie - ponad pięćdziesiąt tytułów (tylko część z nich została przetłumaczona na język polski - wśród nich jednak te najbardziej kanoniczne). Podstawę materiałową stanowi w tym szkicu trzynaście książek - zatem część stosunkowo niewielka. Sądzę jednak, że na tyle wystarczająca, by sformułować kilka uwag mających zastosowanie do całości dzieła Baudrillarda.

Zastrzeżenie trzecie ma charakter merytoryczny. Punktem wyjścia do dalszych rozważań jest teza sformułowana w dwóch świetnych polskich studiach o pisarstwie francuskiego filozofa. Myślę o książkach Agnieszki Ogonowskiej Twórcze metafory medialne. Baudrillard - McLuhan - Goffman oraz Michała Kłosińskiego Ratunkiem jest tylko poezja. Baudrillard Teoria - Literatura. Przedmiotem pierwszej z nich jest użycie w pracach socjologów (m.in. Baudrillarda) języka zmetaforyzowanego do opisu współczesnych mediów, przedmiotem drugiej - rozpoznanie wielorakich powinowactw pisarstwa Baudrillarda $z$ literaturą ${ }^{2}$. W szczególności Michał Kłosiński wielokrotnie i dobitnie formułuje w swojej książce (począwszy od jej wymownego tytułu) tezę o głęboko literackim (poetyckim) charakterze tego pisarstwa, o jego rozległych i zróżnicowanych związkach z literaturą (poezją). Nawiązuje przy tym do wcześniejszych prób podjęcia tego zagadnienia: artykułu Barbary Markowskiej Społeczeństwo a media. Dwugłos: Baudrillard - McLuhan, która w Polsce „jako pierwsza [...] domagała się [...] uwzględnienia tych związków"3 oraz uwag sformułowanych na ten temat przez współautorów poświęconego dwóm książkom Baudrillarda numeru

1 A. Ogonowska, Twórcze metafory medialne. Baudrillard - McLuhan-Goffman, Kraków 2010, s. 259.

2 M. Kłosiński, Ratunkiem jest tylko poezja. Baudrillard - Teoria - Literatura, Warszawa 2015 (zob. zwłaszcza rozdział I: Baudrillard - teoria - poetyka i rozdział V: Baudrillard - teoria - literatura).

3 Ibidem, s. 15. 
czasopisma „Pogranicza”4. Barbara Markowska konstatuje: „Miłość do literatury naznaczyła jego [Baudrillarda - przyp. T.W.] styl pisania, bardziej literacki niż naukowy, bardziej poetycki niż dyskursywny"5.

Nie można się z tą ogólną tezą - dzisiaj już głęboko uzasadnioną i ugruntowaną w polskich badaniach nad pisarstwem francuskiego myśliciela nie zgodzić. Jak wspomniałem, na różne sposoby formułuje i rozwija ją w swojej książce Michał Kłosiński. Nieraz jednak czyni to tak radykalnie, że skłania do polemiki. Przykładowo zauważa, że „cała refleksja teoretyczna Baudrillarda przyjmuje właśnie literaturę za punkt odniesienia [...] kręci się niejako wokół literatury"“. Byłbym nieco ostrożniejszy i myśl tę wyraził w sposób bardziej umiarkowany. Zasadniczym „punktem odniesienia” pozostaje jednak dla teorii francuskiego filozofa - by powiedzieć tradycyjnie i jakby wbrew jego przekonaniu - sfera społeczna. Literatura natomiast - prawda, że w niezmiernie szerokim zakresie i w bardzo różnorodnych formach - służy rozpoznawaniu i diagnozowaniu tej sfery. Traktowanie jej bardziej jako narzędzia niż celu w żadnej mierze nie umniejsza jej roli i znaczenia. W sposób podobnie radykalny charakteryzuje pisarstwo Baudrillarda Agnieszka Ogonowska: „Autor Symulakrów i symulacji uprawia teorię przypominającą w swoim stylu, poetyce i charakterze formy literackie, które realizują przede wszystkim funkcje estetyczne" ${ }^{\text {" }}$. Byłbym skłonny dokonać w tym zdaniu pewnej drobnej, ale istotnej korekty: pisma Baudrillarda rzeczywiście realizują takie „funkcje”, jednak nie „przede wszystkim”, lecz co najwyżej równorzędnie z funkcją poznawczą. Nie zaprzeczam walorom czy wręcz urokom estetycznym tekstów francuskiego myśliciela, ale uważając tę funkcję za kluczową, chcę się o nią upomnieć.

4 Zob. „Pogranicza” 2005, nr 3. Numer zawiera wypowiedzi Ingi Iwasiów (która prowadziła całość dyskusji), Jerzego Kochana, Jerzego Madejskiego, Piotra Michałowskiego, Andrzeja Skrendo, Dariusza Śnieżki i Pawła Wolskiego. W swojej książce Michał Kłosiński omawia je na stronach 19-23.

5 B. Markowska, Społeczeństwo a media. Dwugłos: Baudrillard-McLuhan, „Kultura Popularna“ 2004, nr 1(7), s. 54. Cyt. za: M. Kłosiński, op. cit., s. 15.

${ }^{6}$ M. Kłosiński, op. cit., s. 31.

7 A. Ogonowska, op. cit, s. 259. 
Michał Kłosiński przywołuje w swojej książce - jak zauważa - „najważniejszy tekst poświęcony poetyce Baudrillarda”: artykuł Gerrego Coultera o związkach jego pisarstwa z twórczością Friedricha Hölderlina ${ }^{9}$. I tak wykłada podstawową myśl tego artykułu:

Coulter pokazuje, że Baudrillard nie poddał swojego pisarstwa reżymowi teoretycznego albo czysto socjologicznego dyskursu, aby dla swojej wypowiedzi zachować enigmatyczną siłę języka poetyckiego. [...] Odnajduje zatem jeden z najważniejszych dla całego systemu myślowego Baudrillarda kontekstów i - co szczególnie istotne dla perspektywy lektury literaturoznawczej tekstów francuskiego socjologa - jest to kontekst poetycki, literacki, który źródło najważniejszych i rewolucyjnych tez na temat współczesnego społeczeństwa odnajduje w wierszach i opowieściach ${ }^{10}$.

Zgadzając się z tą myślą, chcę sformułować kilka uwag poświęconych odniesieniom pisarstwa Baudrillarda do literatury. Uwagi te traktuję, z jednej strony, jako uzupełnienie cennych ustaleń Agnieszki Ogonowskiej i Michała Kłosińskiego, uzasadnienie kluczowej tezy ich książek o literackim wymiarze tekstów francuskiego filozofa kilkoma dodatkowymi spostrzeżeniami, z drugiej - jako wskazanie możliwych kierunków dalszych badań nad literacką formą teorii Baudrillarda (szczególnie w zakresie genologii jego pism).

\section{LITERATURA W BIOGRAFII BAUDRILLARDA}

Może warto rozpocząć od kwestii najprostszej, jakby nie dość wyartykułowanej w subtelnych i głębokich studiach o myśli Baudrillarda: od pytania, jak była obecna literatura w jego biografii intelektualnej i naukowej (ale nie tylko - zwyczajnie w biografii). Pytanie to jest o tyle zasadne i istotne, że była obecna nieustannie i na wiele różnych sposobów. Przypomnę, że Baudrillard nie był z wykształcenia ani filozofem, ani socjologiem, lecz filologiem (ściśle - germanistą). Szczególnie bliska była mu więc - jeszcze do tego powrócę - literatura niemieckiego obszaru językowego, co znalazło wyraz w różnych formach jego aktywności. Przede wszystkim we wczesnym

8 M. Kłosiński, op. cit., s. 54.

9 Zob. G. Coulter, Baudrillard and Hölderlin and the Poetic Resolution of the World, „Nebula” 2008, Vol. 5, No. 4.

10 M. Kłosiński, op. cit., ss. 55, 58. 
okresie działalności był tłumaczem szeregu dzieł języka niemieckiego (m.in. Karola Marksa, Bertolta Brechta, Petera Weissa). Wśród tych tłumaczeń - co niezmiernie ważne - były również przekłady wierszy Hölderlina, które długo pozostawały niewydane (aż do publikacji w „Les cahiers de l'Herne” w 2005 roku). W młodości Baudrillard pracował jako lektor literatury niemieckiej w paryskim wydawnictwie Seuil, a w czasopiśmie „Les Temps modernes” publikował artykuły krytyczne o literaturze (obcej). Na szczególne przypomnienie zasługuje jeszcze jeden wymowny fakt z jego biografii pisarskiej: w roku 1978 opublikował (nieprzełożony dotychczas na język polski) tom wierszy L’Ange de stuc (Stiukowy anioł), napisanych zresztą znacznie wcześniej, bo jeszcze w latach pięćdziesiątych ${ }^{11}$.

\section{JAKA LITERATURA?}

W pismach Baudrillarda literatura jest niezmiennie i nieustannie obecna. Dostrzegam przy tym pewną prawidłowość: w jego wczesnych książkach odniesień literackich jest jakby relatywnie mniej, zagęszczają się natomiast w książkach pochodzących z późnej i ostatniej fazy twórczości. Ułożenie kompletnej listy przywoływanych autorów jest teoretycznie możliwe, ale technicznie dość trudne i poznawczo - jeśli każdorazowo nie opatrzy się jej stosownym komentarzem - dosyć jałowe. Dlatego ograniczę się do zestawienia takiej (oczywiście częściowej) listy z dwóch perspektyw, które rzucają interesujące światło na myśl Baudrillarda i formę jej ekspresji. Najpierw wskażę krąg - czy raczej kręgi - przywoływanych autorów wyłonione według klucza merytorycznego (problemowego):

- francuscy pisarze libertyńskiego wieku XVIII, którzy profetycznie zapowiadali nowoczesność: Jean-Jacques Rousseau, Pierre Choderlos de Laclos, Donatien Alphonse François de Sade;

- francuscy poeci wieku XIX (i XX), którzy jako pierwsi formułowali diagnozę nowoczesności: Charles Baudelaire, Arthur Rimbaud, Stéphane Mallarmé, Paul Valéry

- $\quad$ pisarze języka niemieckiego, którzy rozpoznawali nowoczesność nieco później (w XX wieku) i w innym miejscu Europy (chodzi

11 Omawia go w swojej książce Michał Kłosiński. Zob. op. cit., s. 242-263. 
o autorów pochodzących z terenów monarchii austro-węgierskiej): Arthur Schnitzler, Franz Kafka, Robert Musil, Elias Canetti;

- $\quad$ pisarze XIX i XX-wieczni, którzy projektowali wizję przyszłości: Alfred Jarry, Aldous Huxley, George Orwell.

Tę już teraz długą listę można by oczywiście znacznie bardziej rozwinąć. Znaleźliby się na niej liczni autorzy reprezentujący takie literatury, jak: włoska, portugalska, duńska, angielska czy amerykańska.

Druga wybrana perspektywa jest perspektywą gatunkową. Baudrillard odwołuje się ze szczególnym upodobaniem do pewnych konkretnych gatunków literackich - niewątpliwie takich, które najgłębiej przeniknęły do stylu i światopoglądu jego pisarstwa. Reprezentujące je utwory literackie przywołuje w różnych formach: dosłownie cytuje, streszcza, opowiada lub powołuje się na nie - rozwija i interpretuje zaczerpnięte z nich myśli. Niejednokrotnie cytaty z tych utworów wykorzystuje jako motta, a więc umieszcza w miejscach szczególnie eksponowanych. Przykładowo motta opatrujące książkę Pakt jasności. O inteligencji Zła pochodzą z twórczości Jorge Luisa Borgesa i Stanisława Jerzego Leca. W szczególności bliskie Baudrillardowi są cztery gatunki:

- $\quad$ wiersze (najczęściej cytowanym autorem jest najpewniej Hölderlin poeta „czasu marnego”, który w koncepcji francuskiego myśliciela dziś ostatecznie się dopełnia);

- aforyzmy (François de La Rochefoucauld, Jean de La Bruyère, szczególnie ceniony Georg Christoph Lichtenberg, Oscar Wilde, Guido Ceronetti);

- różnego rodzaju utwory narracyjne, często o charakterze parabolicznym/alegorycznym i/lub fantastycznym/surrealistycznym (opowieści, opowiadania, przypowieści, baśnie, bajki - przykładem może być baśń Hansa Christiana Andersena Cień, nowela Franza Kafki Przemiana czy powieść Virgilia Martiniego Świat bez kobiet);

- $\quad$ eseje (autorstwa francuskich klasyków gatunku: Michela de Montaigne'a, Alberta Camus, Emila Ciorana).

Czy jednak Baudrillard ma swoich ulubionych autorów i swoje ulubione teksty? Statystycznie najczęściej przywoływanym pisarzem jest najpewniej Borges (i różne jego opowiadania, w szczególności słynna nowela $O$ ścisłości $w$ nauce opowiadająca o sporządzeniu tak dokładnej mapy, że pokryła 
sobą całe zaznaczone na niej terytorium). Bliskie związki i podobieństwa twórczości obu autorów wskazuje Agnieszka Ogonowska:

Tworzone przez [...] [nich - przyp. T.W.] metaforyzacje świata nie są ani naiwne, ani też nie pełnią wyłącznie funkcji retorycznych ozdobników. Oddają natomiast specyfikę ich umysłowości, niezwykle zbliżone sposoby percepcji zjawisk i istotę tworzonych przez nich systemów filozoficznych. Dzieła Borgesa można zatem odczytywać jako dyskursy naukowe; z kolei pokaźna część tekstów Baudrillarda z powodzeniem może funkcjonować w roli literatury fantastycznej lub fantastycznonaukowej ${ }^{12}$.

Spośród utworów literackich prawie refrenicznie powracają w różnych książkach francuskiego filozofa jego ulubione opowieści o charakterze metaforycznym, parabolicznym, alegorycznym - wielokrotnie przywoływane, streszczane i interpretowane: XVIII-wieczna Bajka o pszczołach Bernarda de Mandeville’a (rzecz o źródle energii, dynamiki i bogactwa społeczeństwa, którym są jego niemoralność, wady i słabości), romantyczna opowiastka Prawdziwa historia Piotra Schlemihla Adalberta von Chamissa (rzecz o człowieku, który zgubił swój cień), współczesne opowiadanie 9 miliardów imion Boga Arthura C. Clarke’a (rzecz o wyliczaniu przez tybetańskich mnichów imion Boga, które to zadanie ostatecznie wykonują informatycy z koncernu IBM). To właśnie przypomnieniami tych utworów Baudrillard chętnie inkrustuje swoje książki, a ich sensami ilustruje i potwierdza swoje rozważania.

Lista pisarzy (i ich utworów) powracających w jego pismach może być - jak zaznaczyłem - znacznie rozleglejsza. Do tej przedłużającej się enumeracji chcę jeszcze dodać osobno akcent polski. W tekstach francuskiego myśliciela są bowiem również obecni XX-wieczni autorzy polscy. Baudrillard w różnych miejscach cytuje kilka aforyzmów wspomnianego już Leca. Odwołuje się także do twórczości Witolda Gombrowicza: cytuje (i komentuje) dłuższe fragmenty Dziennika czy list do Jeana Dubuffeta. W tomie rozmów z Philippe'em Petitem Przed końcem pojawia się Stanisław Ignacy Witkiewicz, ale Baudrillard nie rozwija tego wątku.

12 A. Ogonowska, op. cit., s. 51. 


\section{GATUNKI LITERACKIE BAUDRILLARDA}

Tak jak myśli pisarzy francuski filozof twórczo podejmuje i interpretuje w swoich książkach (bo przecież przywoływane lub cytowane fragmenty ich utworów nie pełnią tylko funkcji prostej egzemplifikacji czy ilustracji), tak gatunki literackie, do których się odwołuje, wnikają głęboko w ich strukturę i styl. Stawiam tezę genologiczną - wymagającą podjęcia wnikliwszych badań - że pisarstwo Baudrillarda (całościowo traktowane) można uznać za sylwiczne czy hybrydyczne, a jako jego kluczową poetykę wskazać poetykę fragmentu. Konieczne jest przy tym zastrzeżenie chronologiczne: teza ta zdaje się mieć zastosowanie szczególnie wobec późnych książek francuskiego filozofa.

Jeszcze jego wczesne pisma - takie jak Społeczeństwo konsumpcyjne, jego mity i struktury czy Wyobraźnia symboliczna i śmierć - mają w swoim stylu i w swojej konstrukcji charakter, by tak rzec, bardziej scjentyczny. W pierwszej z wymienionych książek Baudrillard operuje dyskursem ekonomii (znamienny szczegół: wykorzystuje ścisłe dane liczbowe i precyzyjne wyliczenia procentowe - nawet $\mathrm{w}$ formie tabel). Z czasem jednak ten scjentyczny dyskurs stopniowo zanika, a swoją obecność coraz wyraźniej zaznaczają gatunki właśnie literackie. Literackość czy wręcz poetyckość stylu książek Baudrillarda przekonująco (i od różnych stron) pokazują Agnieszka Ogonowska i Michał Kłosiński.

Do poezji dodałbym jednak jeszcze inne gatunki: aforyzm (wiele myśli francuskiego myśliciela można by wyjąć z jego pism i traktować jako autonomiczne sformułowania aforystyczne), opowieść (późną książkę Zbrodnia doskonała otwiera zdanie brzmiące jak początek utworu narracyjnego - opowiadania czy nawet baśni: „Opowieść ta osnuta będzie wokół zbrodni [...]."13), wreszcie esej (tak przecież brzmią podtytuły późnych książek Baudrillarda: Przejrzystość Zła. Esej o zjawiskach skrajnych i Dlaczego wszystko jeszcze nie zniknęło? Esej ostatni). Oczywiście w jego pisarstwie te wszystkie formy wypowiedzi - rozprawa naukowa, poezja, aforyzm, opowieść, esej - mieszają się ze sobą w różnych układach, wchodzą w różnorodne związki i zależności - jednym słowem, tworzą całość sylwiczno-hybrydyczną. Za wymownie symboliczny dla praktyki mieszania

${ }_{13}$ J. Baudrillard, Zbrodnia doskonała, tłum. S. Królak, Warszawa 2008, s. 7. 
gatunków - dla zjawiska ich swobodnego krążenia w przestrzeni całego dzieła - trzeba uznać fakt, że tytułem swojego tomu poetyckiego (Stiukowy anioł) Baudrillard opatrzył jeden z rozdziałów książki Wymiana symboliczna $i$ śmierć. Taki jest więc zasadniczy rys gatunkowy pisarstwa francuskiego filozofa - rys coraz wyraźniejszy w jego późnych książkach, w których rośnie rola i znaczenie takich gatunków, jak wiersz, aforyzm, opowieść i esej.

Równocześnie książki te w coraz większym stopniu określa poetyka fragmentu. W ich stylu nasila się tendencja do kształtowania wywodu z osobnych i krótkich (nieraz nawet jednozdaniowych) akapitów (dobrym przykładem jest tom Pakt jasności. O inteligencji Zła). Inny przykład książki z założenia fragmentarycznej w swojej kompozycji stanowi późny tom Słowa klucze - rodzaj słownika najważniejszych pojęć używanych przez Baudrillarda i zwięzłego komentarza do nich. Niektóre pojęcia brzmią tak jak tytuły wcześniejszych książek, co sprawia, że słownik ten jest zbiorem fragmentów - esencjonalnych skrótów czy streszczeń tych książek. Skrajną postać poetyka fragmentu przybiera w książce Dlaczego wszystko jeszcze nie zniknęło?, która jest równocześnie esejem (zgodnie z jej podtytułem: Esej ostatni) i luźnym zbiorem uwag. Zatem - powtórzę szczególnie w odniesieniu do późnych książek Baudrillarda - jego pisarstwo można odczytywać jako (jednocześnie) sylwiczno-hybrydyczne i fragmentaryczne.

\section{MOŻLIWE PARALELE}

Literatura wnika więc głęboko w strukturę myślową (problemową) i formalną (gatunkową) pism francuskiego myśliciela. A jeśli tak, to paralele literackie, które można by podjąć (i które zostały już w badaniach podjęte), są liczne i różnorodne. Sam Baudrillard jednoznacznie wskazał swoim dziełem chociażby na szczególnie inspirującą dla niego rolę poezji Hölderlina i prozy Borgesa.

Ograniczę się w tym miejscu do zarysowania możliwości polskich paralel. Jedną z nich przeprowadził Michał Kłosiński, zestawiając myśl francuskiego filozofa z pisarstwem Brunona Schulza (ściśle - z jego szkicem Mityzacja rzeczywistości $)^{14}$. Podjąłem kiedyś próbę równoległej lektury pism Baudrillarda

${ }_{14}$ M. Kłosiński, op. cit., s. 272-288. Zob. również: D. Głowacka, Wzniosła tandeta i simulacrum: Bruno Schulz w postmodernistycznych zaułkach, „Teksty Drugie” 1996, nr 2/3 oraz: J. Olejniczak, Miejsce Schulza w literaturze modernistycznej, [w:] Narracje po 
i wierszy Bolesława Leśmiana ${ }^{15}$. Na taką lekturę czeka jednak moim zdaniem również twórczość innych polskich pisarzy (zwłaszcza XX wieku): wskażę przykładowo - w trybie hipotezy badawczej (porównawczej) - wspomnianych już Witkiewicza i Gombrowicza czy Tadeusza Różewicza.

To właśnie Różewicz będzie bohaterem tych uwag. Z obszernego pisarstwa Baudrillarda (ściśle - z książki Przejrzystość Zła. Esej o zjawiskach skrajnych) i rozległej poezji Różewicza wybieram jeden tylko wspólny fragment-obraz. Jedyna różnica polega na tym, że Baudrillard dodaje do niego interpretacyjny komentarz, czego oczywiście nie czyni w swoim wierszu (zatytułowanym maison de retraite) Różewicz. Przypomnę jeszcze, że wiersz ten (pochodzący z tomu zawsze fragment. recycling) jest poświęcony ostatniemu epizodowi w biografii Samuela Becketta - pobytowi w domu starości:

na końcu korytarza

w tunelu bez światła

siedzi i patrzy godzinami

w zgaszony telewizor ${ }^{16}$

Widok człowieka znieruchomiałego i wpatrzonego w akcie protestu w pusty ekran telewizora będzie kiedyś jednym z najbardziej wymownych obrazów dwudziestowiecznej antropologii ${ }^{17}$.

Chyba już jest. A znaczenia tego obrazu - pozwolę sobie poprawić Baudrillarda - nie można zredukować wyłącznie do „aktu protestu”. Jego metaforyczny sens jest - jak myślę - znacznie szerszy.

\section{UWAGI ZAMYKAJĄCE}

W tytule tego szkicu użyłem - w trybie koniunkcji - dwóch pojęć: „socjologia” oraz literatura. Nie jest jednak oczywiście tak, że są to pojęcia osobne

końcu (wielkich) narracji. Kolekcje, obiekty, symulakra..., red. H. Gosk, A. Zieniewicz, Warszawa 2007, s. 303-314.

15 Zob. T. Wójcik, Bolesław Leśmian - Jean Baudrillard. Inicjalne narracje sprzed końca, [w:] Narracje po końcu (wielkich) narracji..., s. 290-301.

16 T. Różewicz, zawsze fragment. recycling, Wrocław 1998, s. 65.

17 J. Baudrillard, Przejrzystość Zła. Esej o zjawiskach skrajnych, tłum. S. Królak, Warszawa 2009, s. 17. 
i równorzędne, a dzieło pisarskie francuskiego myśliciela stanowi ich prostą sumę czy mechaniczne połączenie. Dlatego próbowałem pokazać rolę i znaczenie literatury dla kształtu tego „socjologicznego” dzieła. Stąd z kolei tak wyraźna dominacja literaturoznawczej czy - ściślej nawet - poetologicznej (zwłaszcza genologicznej) perspektywy jego opisu.

Twierdzenie, że pisarstwo Baudrillarda nie jest prostą sumą „socjologii” i literatury trzeba zresztą rozumieć znacznie szerzej: należy je odnieść do wszystkich dziedzin, których języków i metod używa francuski filozof. To właśnie językowy i metodologiczny eklektyzm tego pisarstwa sprawia, że jego dzieło wymyka się oczywistym i jednoznacznym kwalifikacjom gatunkowym. Słowa „eklektyzm” używam przy tym w znaczeniu opisowym, w żadnej mierze nie wartościującym. I zarazem zgodnie z postulatem czy dyrektywą sformułowaną przez samego Baudrillarda:

Poznać wszystkie dyscypliny, aby dotrzeć do tajemnicy ich przedmiotu. Używać ich na sposób transwersalny, aluzyjny, metaforyczny, eliptyczny, ironiczny - nie realistyczny, nie obiektywny, nie metodyczny, nie referencyjny ${ }^{18}$.

Jak zatem na tym hybrydycznym/sylwicznym i fragmentarycznym tle usytuować „socjologię”? Można by w pierwszym odruchu odpowiedzieć, że pytanie jest niewłaściwie postawione. Przesądza o tym sam Baudrillard, który w swoich książkach wielokrotnie i stanowczo podkreśla, że nie jest socjologiem. Tak właśnie definiuje siebie - by ograniczyć się do jednego, ale bardzo wyrazistego przykładu - w tomie rozmów Przed końcem:

Nigdy nie byłem socjologiem [...]. Bardzo szybko oderwałem się od socjologii instytucji, prawa, struktur społecznych, od podejść opartych o wyobrażenie sfery społecznej, o ideę jej transcendencji. [...] Tym, co zarzucam socjologii, jest w gruncie rzeczy jej realizm, to, że społeczne bierze za społeczne i nie próbuje nawet wziąć pod uwagę czegoś innego [...] jakby wymiar społeczny był czymś danym. [...] Socjologia [...] z oczywistego, niepodważalnego istnienia sfery społecznej uczyniła rodzaj postulatu, w którym istnienia sfery społecznej dowodzi samo jej istnienie, tautologia tkwiąca dzisiaj niefortunnie u podstaw wszystkich nauk humanistycznych ${ }^{19}$.

18 J. Baudrillard, Przed końcem. Rozmawia Philippe Petit, tłum. R. Lis, Warszawa 2001, s. 145-146.

19 Ibidem, s. 56-57. 
Należałoby dodać (zapytać): jak Baudrillard ma/może być socjologiem, jeśli w tylu miejscach swoich pism kwestionuje istnienie samego przedmiotu socjologii? Przywołam znowu tylko jego pojedyncze wypowiedzi, brzmiące jednak jednoznacznie i kategorycznie. W tym samym zbiorze rozmów odpowiadając (sobie) na pytanie: „Czego nie należy zasłaniać?” - stwierdza: „Tego, co w społeczeństwie nie daje się sprowadzić do społeczeństwa jako takiego"20. I dopowiada:

W każdym razie, kiedy socjologia wygłosi w końcu kilka spójnych sądów o tym, co społeczne, społeczeństwo już dawno zniknie. Już teraz znajduje się na najlepszej drodze do zniknięcia. Jedynie socjologiczny metajęzyk zachowuje pamięć o tej skamielinie ${ }^{21}$.

Nie ma powodu, by nie traktować tych wypowiedzi z dobrą wolą. Jak jednak wtedy uzgodnić je z rozpowszechnionym przekonaniem, że Baudrillard był socjologiem, a przedmiot jego badań stanowiła sfera społeczna? Żeby wybrnąć z tego dylematu, znawcy i badacze pisarstwa francuskiego myśliciela - także polscy - (chętnie) używają pojęcia „miękka” socjologia. Pojawia się jednak pytanie, co w istocie oznacza to pojęcie, tym bardziej, że jest przecież metaforyczne, a metafora - zgodnie ze swoją naturą - może mieć różne i niezliczone wykładnie.

Uzasadnienie dla niego widziałbym w pewnym szczególnym związku, w pewnej szczególnej jedności czy konsekwencji, która stanowi - jak myślę fundament pisarstwa Baudrillarda. Za fundament ten uznałbym odpowiedniość pomiędzy zmiennością, pustką czy wręcz nieistnieniem przedmiotu badań i językiem czy metodą jego opisu. Tę zależność można by ująć w taki sposób: społeczne jako przedmiot badań nieustannie się oddala, wymyka, zanika, zatem metoda musi za nim - równie nieustannie - podążać czy raczej nadążać. Nie jest to więc - bo być nie może - metoda opisu gotowego, trwałego, niezmiennego przedmiotu, lecz pościgu za przedmiotem, jak zaznaczyłem, oddalającym się, wymykającym, zanikającym. Mówiąc metaforycznie: tabele $z$ danymi statystycznymi (cyfrowymi, liczbowymi), które Baudrillard - jako narzędzia „twardej” socjologii - wykorzystywał w swoich wczesnych książkach, z czasem się rozpadły. Ich miejsce i funkcję

20 Ibidem, s. 145.

${ }^{21}$ Ibidem, s. 146. 
zajęły czy przejęły inne języki, inne metody - wśród nich (i w bardzo doniosły sposób) literatura.

Dla uprawiania tej „miękkiej” socjologii - jeśli jednak zachować ten termin z braku lepszego (choć Baudrillard by go nie zaakceptował) - właśnie literatura okazała się dla francuskiego filozofa niezmiernie pomocna i pożyteczna, oddała mu różne i ważne przysługi. W tym sensie - co chcę wyraźnie podkreślić - nie można zredukować jej znaczenia do roli ilustracji, ornamentu czy tym bardziej dodatku. Widziałbym w niej raczej istotę stylu Baudrillarda - stylu adekwatnego do przedmiotu badań. Potwierdza to właściwie każdy z gatunków, do których odwołuje się i których języka używa francuski myśliciel:

- wiersz: bo niejednoznaczność przedmiotu rozpoznaje się za pomocą właściwego poezji języka wieloznacznych metafor;

- aforyzm: bo za „uciekającym” przedmiotem podąża się stylem pospiesznym, „zdyszanym”, eliptycznym;

- opowieść: bo przedmiot rozumiany nie jako stabilny stan, lecz jako dynamiczny proces opisuje się językiem narracyjnie rozwijającym się w czasie;

- $\quad$ esej: bo przedmiot o zatartych i płynnych konturach rozważa się w stylu nie dogmatycznym, lecz konsyderacyjnym.

Chociaż użyłem pojęć „stylu” i ,języka”, chodzi w istocie o metodę, która jest dopasowana do jej obiektu. Mówiąc jeszcze inaczej: „miękki” obiekt domaga się „miękkiej” metody, „miękkiej” socjologii. Ale ta „miękkość" - powtórzę - jest nie tylko czy nie przede wszystkim kwestią stylu czy języka, lecz - docelowo i ostatecznie - właśnie metody. Udział literatury w jej kształtowaniu, w określaniu jej podstaw i reguł jest zupełnie nie do przecenienia. Zatem koniunkcja pojęć: „socjologia” i literatura ma szczególne znaczenie. Można - ujmując tę relację w sposób być może skrajny powiedzieć, że uprawiając „miękką” socjologię, Jean Baudrillard tworzy literaturę, zaś tworząc literaturę, uprawia „miękką” socjologię. Dziedziny te prześwitują wzajemnie przez siebie, by utracić swoją osobność i rozpłynąć się w ścisłej jedności. 


\section{Bibliografia}

Jean Baudrillard, Ameryka, tłum. R. Lis, Sic!, Warszawa 1998.

Jean Baudrillard, Dlaczego wszystko jeszcze nie zniknęło? Esej ostatni, tłum. S. Królak, Sic!, Warszawa 2009.

Jean Baudrillard, O uwodzeniu, tłum. J. Margański, Sic!, Warszawa 2005.

Jean Baudrillard, Pakt jasności. O inteligencji Zła, tłum. S. Królak, Sic!, Warszawa 2005. Jean Baudrillard, Przed końcem. Rozmawia Philippe Petit, tłum. R. Lis, Sic!, Warszawa 2001.

Jean Baudrillard, Przejrzystość Zła. Esej o zjawiskach skrajnych, tłum. S. Królak, Sic!, Warszawa 2009.

Jean Baudrillard, Słowa klucze, tłum. S. Królak, Sic!, Warszawa 2008.

Jean Baudrillard, Spisek sztuki. Iluzje i deziluzje estetyczne $z$ dodatkiem wywiadów o „Spisku sztuki“, przedmowa: S. Lotringer, tłum. S. Królak, Sic!, Warszawa 2006.

Jean Baudrillard, Społeczeństwo konsumpcyjne, jego mity i struktury, tłum. S. Królak, Sic!, Warszawa 2006.

Jean Baudrillard, Symulakry i symulacja, tłum. S. Królak, Sic!, Warszawa 2005.

Jean Baudrillard, W cieniu milczącej większości albo kres sfery społecznej, tłum.

S. Królak, Sic!, Warszawa 2006.

Jean Baudrillard, Wymiana symboliczna i śmierć, tłum. S. Królak, Sic!, Warszawa 2007. Jean Baudrillard, Zbrodnia doskonała, tłum. S. Królak, Sic!, Warszawa 2008.

Gerry Coulter, Baudrillard and Hölderlin and the Poetic Resolution of the World, „Nebula” 2008, Vol. 5, No. 4.

Dorota Głowacka, Wzniosła tandeta i simulacrum: Bruno Schulz w postmodernistycznych zautkach, „Teksty Drugie” 1996, nr 2/3.

Michał Kłosiński, Ratunkiem jest tylko poezja. Baudrillard - Teoria - Literatura, IBL PAN, Warszawa 2015.

Agnieszka Ogonowska, Twórcze metafory medialne. Baudrillard-McLuhan - Goffman, Universitas, Kraków 2010.

Józef Olejniczak, Miejsce Schulza w literaturze modernistycznej, [w:] Narracje po końcu (wielkich) narracji. Kolekcje, obiekty, symulakra..., red. H. Gosk, A. Zieniewicz, Dom Wydawniczy Elipsa, Warszawa 2007.

Tadeusz Różewicz, zawsze fragment. recycling, Wydawnictwo Dolnośląskie, Wrocław 1998.

Tomasz Wójcik, Bolesław Leśmian - Jean Baudrillard. Inicjalne narracje sprzed końca, [w:] Narracje po końcu (wielkich) narracji. Kolekcje, obiekty, symulakra..., red. H. Gosk, A. Zieniewicz, Dom Wydawniczy Elipsa, Warszawa 2007. 


\section{Jean Baudrillard. 'Sociology' and Poetics}

The sketch is an attempt at a structured reflection concerning the issue of the presence of literature in the writings of Jean Baudrillard (various forms and meanings of this presence). It complements the books by Agnieszka Ogonowska Twórcze metafory medialne. Baudrillard - McLuhan - Goffman and Michał Kłosiński Ratunkiem jest tylko poezja. Baudrillard-Teoria-Literatura, and at the same time it outlines the possibilities of further research on this issue (especially in the genology of writings by the French sociologist).

Keywords: Jean Baudrillard, 'sociology', poetics, literature

Data otrzymania tekstu: 4.05.2020 r.

Data zakończenia procesu recenzyjnego: 12.01.2021 r.

Data akceptacji tekstu do druku: 18.01.2021 r. 
